\section{EOT 608953}

2. To: (Receiving Organization) Distribution

5. Proj./Prog./Dept./Div.:

$W-100$

8. Originator Remarks:

For release.

11. Receiver Remarks:

3. From: (originating Organization)
7FD60
6. Cog. Engr.:
G. F. Boothe

3. From: (originating Organization)

6. 'Cog. Engr.:
4. Related EDT No.:

$N / A$

7. Purchase Order No.:

$N / A$

9. Equip./Component Mo.: $N / A$

10. System/Bldg./Facility: N/A

12. Major Assm. Dwg. No.: $N / A$

13. Permit/Permit Application No.: N/A

14. Required Response Date: $N / A$

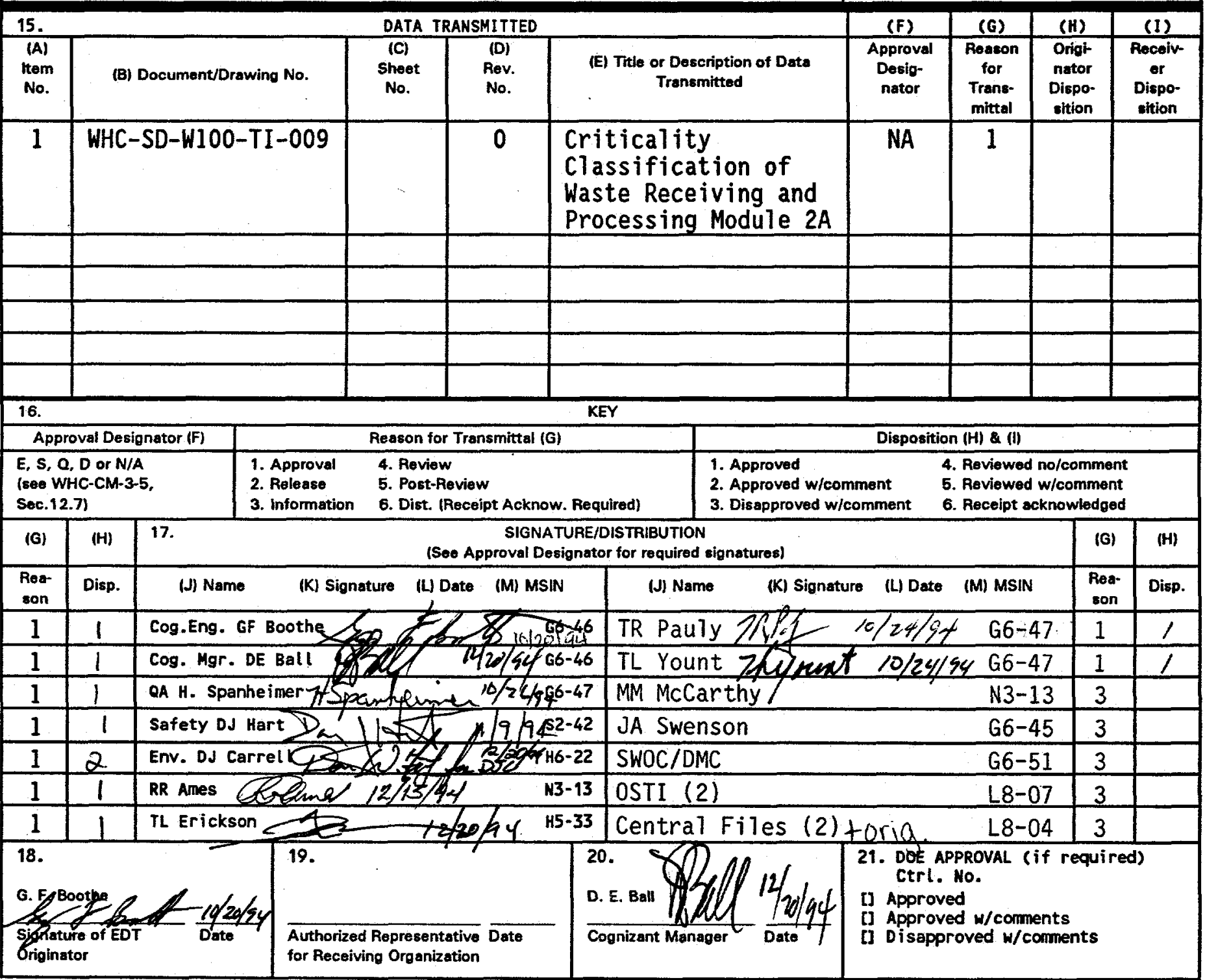




\section{DISCLAIMER}

Portions of this document may be illegible in electronic image products. Images are produced from the best available original document. 


\section{RELEASE AUTHORIZATION}

Document Number:

WHC-SD-W100-TI-009, REV. O

Document

Title:
Criticality Classification of Waste Receiving and Processing Module $2 \mathrm{~A}$

\section{Release Date: 12/22/94}

\section{This document was reviewed following the procedures described in WHC-CM-3-4 and is:}

\section{APPROVED FOR PUBLIC RELEASE}

WHC Information Release Administration Specialist:

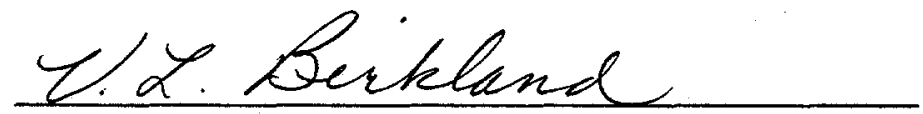

\section{v. L. Birkland}

TRADEMARK DISCLAIMER. Reference herein to any specific commercial product, process, or service by trade name, trademark, manufacturer, or otherwise, does not necessarily constitute or imply its endorsenent, recomendation, or favoring by the United States Government or any agency thereof or its contractors or subcontractors.

This report has been reproduced from the best available copy. Available in paper copy and microfiche. Printed in the United States of America. Available to the U.S. Department of Energy and its contractors from:

U.S. Department of Energy

office of Scientific and Technical Information (OSTI)

P.0. Box 62

Oak Ridge, TN 37831

Telephone: (615) 576-8401

Available to the public from:

U.S. Department of Commerce

Kational Technical Information Service (NTIS)

5285 Port Royal Road

Springfield, VA 22161

Telephone: (703) 487-4650 
2. Title

Criticality Classification of Waste Receiving and Processing Module 2A

5. Key Words

criticality, WRAP 2A, TRU
3. Nunber

WHC-SD-W100-TI-009

4. Rev No.

0

6. Author

Name: G. F. Boothe

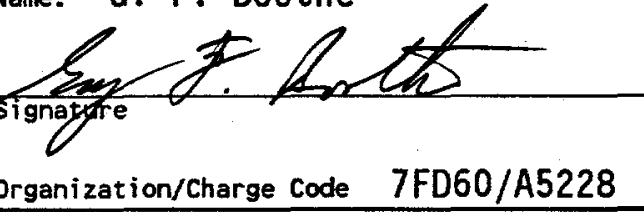

7. Abstract

The design basis inventory for WRAP $2 A$ is described and compared with the fissionable material exempt quantity. The WRAP $2 A$ process is also described, relative to the potential for concentrating or accumulating fissionable material within the facility.

8.

RELEASE STAMP

OFFICIAL RELEASE BYWHC

DATE DEC 271994

35 Station 21 


\title{
CRITICALITY CLASSIFICATION OF WASTE RECEIVING AND PROCESSING MODULE $2 A$
}

\author{
October 1994
}

Gary $F$. Boothe

\section{DISCLAIMER}

This report was prepared as an account of work sponsored by an agency of the United States Government. Neither the United States Government nor any agency thereof, nor any of their employees, makes any warranty, express or implied, or assumes any legal liability or responsibility for the accuracy, completeness, or usefulness of any information, apparatus, product, or process disclosed, or represents that its use would not infringe privately owned rights. Reference herein to any specific commercial product, process, or service by trade name, trademark, manufacturer, or otherwise does not necessarily constitute or imply its endorsement, recommendation, or favoring by the United States Government or any agency thereof. The views and opinions of authors expressed herein do not necessarily state or reflect those of the United States Government or any agency thereof.

\section{Westinghouse Hanford Company \\ Richland, Washington}


WHC-SD-W100-TI-009 REV 0

\section{CONTENTS}

1.0 INTRODUCTION $\ldots \ldots \ldots \ldots \ldots \ldots$

2.0 SOURCE TERMS AND INVENTORIES ............... 1

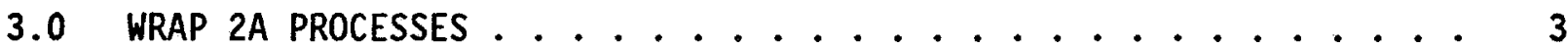

4.0 CONCLUSIONS ..................... 7

5.0 REFERENCES ................... 7 


\section{CRITICALITY CLASSIFICATION OF WASTE \\ RECEIVING AND PROCESSING MODULE 2A}

\subsection{INTRODUCTION}

The purpose of this document is to evaluate the criticality potential of the Waste Receiving and Processing Module 2A (WRAP 2A) and to demonstrate that the facility is an exempt facility, under the provisions of the Nuclear Criticality Safety Manual (WHC 1994). The WRAP 2A maximum potential transuranic (TRU) contents of feedstreams and product inventories are discussed. Total plant fissionable materials are estimated. The WRAP 2A operations and processes are then discussed relative to the potential concentration of fissionable material and criticality safety.

\subsection{SOURCE TERMS AND INVENTORIES}

The purpose of the WRAP $2 A$ facility is to treat contact-handled ( $<200 \mathrm{mrem} / \mathrm{hr}$ ), low-level (non-TRU), radioactive mixed waste so that it will be suitable for mixed waste trench burial at Hanford. The facility will receive drummed and boxed waste from 17 waste streams, consisting of sludge, debris, and particulate. The waste is "conditioned", and then mixed with either grout or polyethylene. This mixture is loaded into boxes $(4 \times 4 \times 4 \mathrm{ft})$ and then disposed of in the mixed waste trench.

A change in the initial Functional Design Criteria and initial facility design greatly lowered the potential facility inventory of fissionable materials. Primarily, the change resulted in the removal of incoming lag storage and the cure storage of product boxes, which was the greater part of the total inventory, as initially specified in the source term document (Boothe 1994). 
A conservative design basis inventory for WRAP $2 A$, consistent with the current facility design, is as follows:

1. Waste Que Storage

2. Drum Elevator

3. Waste Drum Accumulation Conveyors

4. Particulate Grout Mixing Tanks

5. Particulate Grout Product Box

6. Debris Product Box

7. PE dryer

8. PE Feed Hopper

9. PE Product Box Filling

10. PE product Box Cooling Storage

11. Box Breakdown Area

12. Sample Management Area

13. Sample Management Area

TOTAL
12 drums on 3 pallets

1 drum

6 drums

8 DE (4 drum per tank)

4 DE (1 product box)

6 DE (1 product box)

$2 \mathrm{DE}$

$10 \mathrm{DE}$

$7 \mathrm{DE}$ (1 product box)

$14 \mathrm{DE}$ (2 product boxes)

$15 \mathrm{DE}(4 \times 4 \times 8 \mathrm{ft}$ waste box)

1 drum

4 DE (1 product box)

90 drum equivalent

$D E=$ drum equivalent $=7.4$ cubic feet of waste volume

Assuming that each drum equivalent (DE) could contain the maximum 100 $\mathrm{nCi} / \mathrm{g}$ of TRU, and that each DE weighs $135 \mathrm{~kg}$, and assuming $12 \% \mathrm{Pu}-240 \quad 0.175$ $\mathrm{Ci} / \mathrm{g}$, the total maximum possible TRU facility inventory is given by:

$(90 \mathrm{DE} \times 1.0 \mathrm{E}-7 \mathrm{Ci} / \mathrm{g} \times 135,000 \mathrm{~g} / \mathrm{DE}) /(0.175 \mathrm{Ci} / \mathrm{g})=6.9 \mathrm{~g} \mathrm{TRU}$

It should be emphasized that the above inventory is not credible and is overly conservative. This inventory should not be used for any purpose other than this document. Also, it is noted that Np-237 occurs in the feed specification for WRAP $2 A$ and in the hazard categorization document. However, the Np-237 meets the exempt materials requirements of Section 5 of the criticality safety manual due to moderation in the waste matrix. The typical drum in WRAP $2 \mathrm{~A}$ will have much less than $100 \mathrm{nCi} / \mathrm{g}$ of TRU. The actual TRU anticipated in the waste streams is indicated by the alpha content in the Table, which was derived for contamination control purposes and is repeated here in its entirety. 
Besides TRU, the only other significant fissionable material that may enter the WRAP 2A facility is U-235 (assumed to be $1 \%$ enriched). The total quantity of U-235 in 219 existing drum equivalents of debris waste is 22.8 grams and forecast waste is not expected to differ significantly. All received waste will meet the facility fissile inventory restrictions, based on TRU plus U-235 content. The exempt facility 7 imit of $3 \%$ of a minimum critical mass can take the enrichment value into account, but for comparison, the exempt quantity of fully enriched uranium is about 24 grams of U-235. Natural and depleted uranium are not controlled for criticality safety.

\subsection{WRAP 2A PROCESSES}

The conditioning and treatment of the WRAP $2 A$ feedstreams prior to immobilization with grout or polyethylene is described thoroughly in the Advanced Conceptual Design Report, and consists only of:

1. Size Reduction. For example, in the box breakdown area, large items will be crushed, sawed, etc., so that they will be suitable for immobilization with grout or polyethylene.

2. Screening. The particulate and sludge will pass through screens to separate fines from larger items, prior to mixing with grout or polyethylene.

3. Chemically Neutralizing or Deactivating Contained Liquids. This pretreatment (conditioning) will be accomplished in fume hoods adjacent to the main processing line. It is not credible that fissionable material would be significantly concentrated by this chemical treatment, since the contained liquids probably do not contain the material in the first place, and secondly, the volume of chemicals treated at one time (1iter quantities) is small. For example, the maximum amount of TRU contained in an entire liter of contained liquid could only be about 0.00167 grams, even if the Tiquid had $100 \mathrm{nCi} / \mathrm{gram}$ TRU. 


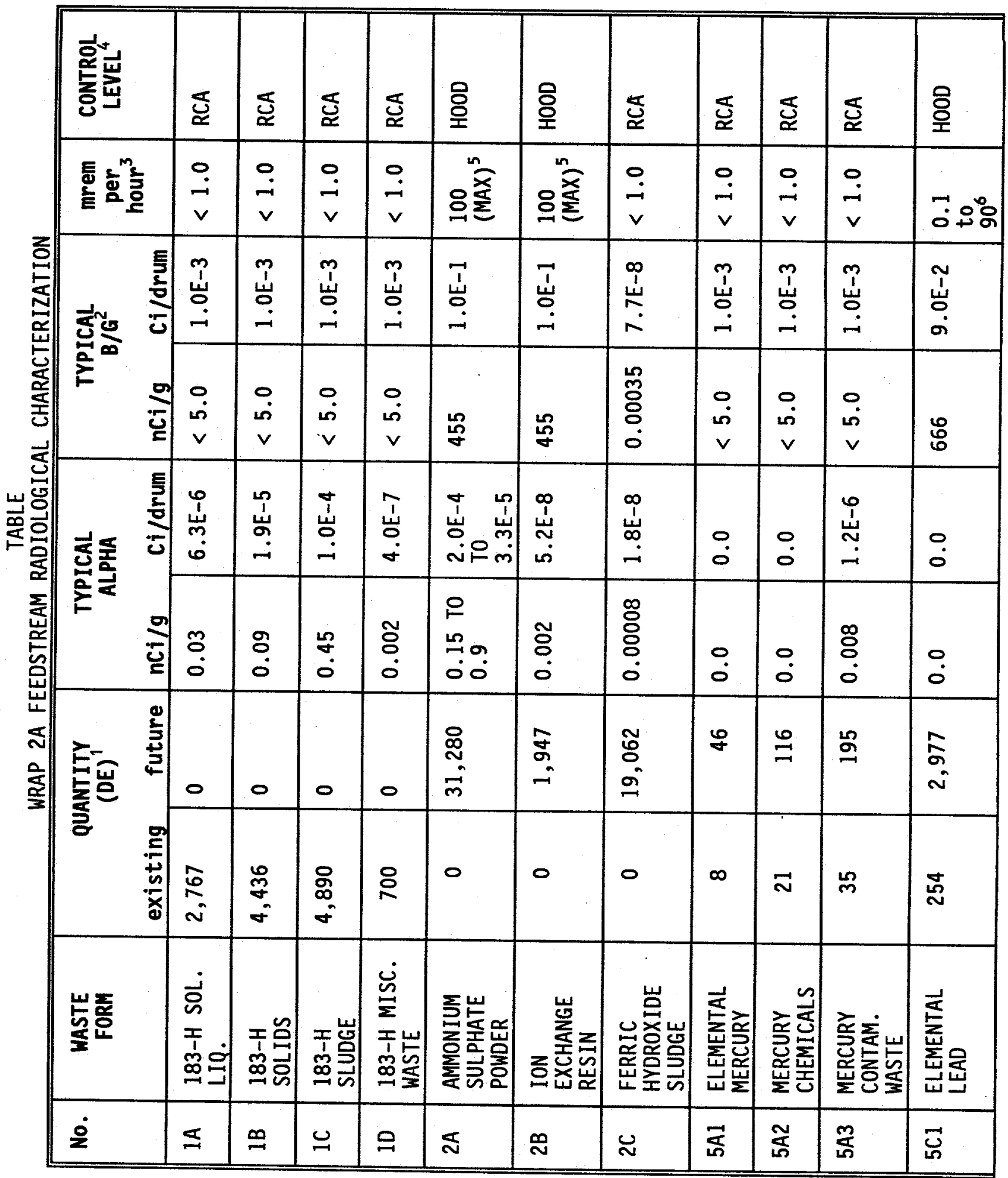




\begin{tabular}{|c|c|c|c|c|c|c|}
\hline 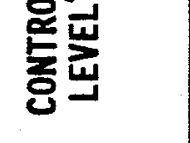 & 우 & 홍 & 호 & 홍. & 호 & ్ㅗ. \\
\hline 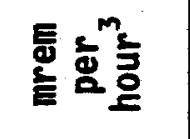 & مُ & \% & 8交 & ப்요 & $\overrightarrow{0} \dot{0} \circ \stackrel{\circ}{\circ}$ & $\ddot{0} \div$ \\
\hline \multirow{2}{*}{ 递客 } & $\begin{array}{l}m \\
\stackrel{1}{4} \\
m \\
m\end{array}$ & $\begin{array}{r}\tilde{U} \\
\stackrel{\tilde{o}}{\Delta} \\
\end{array}$ & 离 & $\begin{array}{l}\tilde{u} \\
\stackrel{u}{u} \\
\end{array}$ & $\begin{array}{l}\tilde{1} \\
\tilde{u} \\
\sigma\end{array}$ & $\begin{array}{l}\tilde{u} \\
\stackrel{u}{u} \\
\dot{\sigma}\end{array}$ \\
\hline & $\stackrel{\mathscr{N}}{v}$ & $\underset{⿱ n}{\infty}$ & $\vec{N}$ & $\mathbb{\infty}$ & $\stackrel{\Re}{R}$ & $\stackrel{m}{m}$ \\
\hline \multirow{2}{*}{ 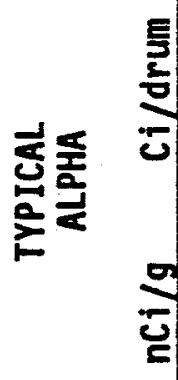 } & $\stackrel{0}{\circ}$ & $\stackrel{0}{0}$ & $\begin{array}{l}\stackrel{n}{u} \\
\dot{o} \\
\dot{\sigma}\end{array}$ & 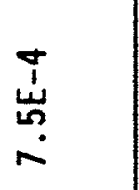 & 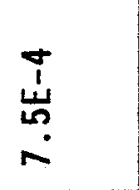 & $\ddot{0}$ \\
\hline & 0 & $\ddot{0}$ & $\stackrel{0}{\infty}$ & مُ & ن் & $\dot{0}$ \\
\hline \multirow{2}{*}{ 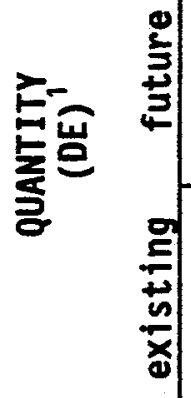 } & مـ & oे & $\begin{array}{l}\overrightarrow{\tilde{m}} \\
\bar{\sigma}\end{array}$ & 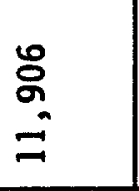 & $\begin{array}{l}\overline{1} \\
\overline{0}\end{array}$ & $\begin{array}{l}8 \\
\text { i }\end{array}$ \\
\hline & - & ஜ & 0 & $\stackrel{\mathscr{్}}{ }$ & $\cong$ & $\mathscr{2}$ \\
\hline 는홍 & 异密 & 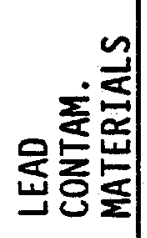 & 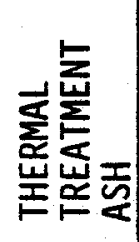 & 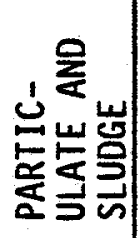 & 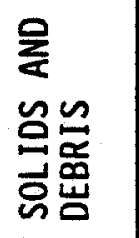 & 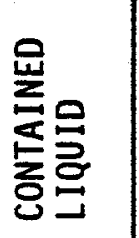 \\
\hline$\dot{0}$ & 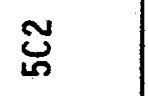 & 总 & $n$ & ธ & ஜ & ઠூ \\
\hline
\end{tabular}


NOTES :

1. DE means 55 gallon $\left(7,4 \mathrm{ft}^{3}\right)$ drum equivalents. Two drum densities are assumed for the feedstreams when calculating radionuclide concentrations from total Curie content. A density of $1.06 \mathrm{~g} / \mathrm{cm}^{3}$ (sludge) is assumed for $1 A, 1 B, 1 C, 1 D, 2 A, 2 B, 2 C, 7$, and $9 A$. A density of $0.65 \mathrm{~g} / \mathrm{cm}^{3}$ (cellulose) is assumed for the other feedstream drums. Waste boxes are assumed to be equivalent to 4.5 drums.

2. $B / G$ means beta/gamma emitters. The total curie content of beta/gamma was usually determined from the recorded external dose rate of waste drums, assuming ORIGEN waste decayed 25 years and a waste matrix density of $0.65 \mathrm{~g} / \mathrm{cm}^{3}$. The external dose rate data is considered more reliable than other estimates of radionuclide content, which are not always consistent with the dose rates. Also, the dose rate quantifies the more critical radionuclides relative to radiation protection and containment requirements.

3. It is conservatively assumed that a drum contact dose rate of 1.0 $\mathrm{mrem} / \mathrm{hr}$ results from $0.001 \mathrm{Ci}$ of MFP.

4. Control level is either containment in a glovebox or hood, or control in a RCA. An alternative would be to handle waste in a HEPA-filtered, ventilated area that is on-mask. The latter type of containment is not preferred or recommended from a radiological protection standpoint. The control-level criteria used is from the Radiological Design manual (WHC 1988). Feedstreams 1A, 1B, IC, 2A, 2C, 7, and 9A were assumed to have highly dispersible contamination. The other feedstreams were assumed to have moderately dispersible contamination. For a drum containing gram quantities of alpha, the effective "hood threshold" is $2.0 \mathrm{nCi} / \mathrm{g}$ alpha activity. For a waste matrix containing up to $1,000 \mathrm{nCi} / \mathrm{g}$ of moderately dispersible beta/gamma, the WHC-CM-4-9 criteria results in a "hood threshold" of $0.001 \mathrm{Ci}$ of MFP per drum, which is essentially a drum that reads $1.0 \mathrm{mrem} / \mathrm{hr}$.

5. The need for a hood is due to the high content of MFP that is assumed for a portion of this feedstream. What fraction of the feed drums that would exceed the hood threshold of $1.0 \mathrm{mrem} / \mathrm{hr}$ is not known at this time.

6. It is estimated that $80 \%$ of the drums in retrievable storage and $96 \%$ of the low-level waste (LLW) drums in the Central Waste Complex (CWC) read less than $1.0 \mathrm{mrem} / \mathrm{hr}$ and are therefore below the beta/gamma hood threshold of $0.001 \mathrm{Ci} /$ drum dictated by $\mathrm{WHC}-\mathrm{CM}-4-9$. The percentages were derived from the recorded dose rates for drums in retrievable storage and the CWC. 


\section{WHC-SD-W100-TI-009 REV 0}

\subsection{CONCLUSIONS}

As can be seen from the above, the inventory of fissionable material within the facility cannot exceed $6.9 \mathrm{~g}$ TRU or $22.814 \mathrm{~g} \mathrm{U}-235$ and there is no process that would significantly concentrate or differentiate the small concentrations of TRU or U-235 in the feedstreams. Therefore the total facility inventory will always be far below the exempt quantity 1 imit of $3 \%$ of a critical mass of fissionable materials. The WRAP 2A facility is therefore an exempt facility under the provisions of the criticality safety manual.

\subsection{REFERENCES}

Boothe, G. F., 1994, Radiological and Chemical Source Terms for Solid Waste Operations Complex, WHC-SD-W306-TI-110, Rev 1, Westinghouse Hanford Company, Richland, Washington.

WHC, 1994, Nuclear Criticality Safety Manual, WHC-CM-4-29, Westinghouse Hanford Company, Richland, Washington.

WHC, 1988, Radiological Design, WHC-CM-4-9, Revision 0, Section 5, Figures 1-4, Westinghouse Hanford Company, Richland, Washington. 